\title{
Expression and activity of superoxide dismutase isoenzymes in colorectal cancer
}

\author{
Michał Skrzycki, Monika Majewska, Małgorzata Podsiad, Hanna Czeczot ${ }^{\bowtie}$ \\ Chair and Department of Biochemistry, Warsaw Medical University, Warszawa, Poland
}

Received: 08 June, 2009; revised: 15 September, 2009; accepted: 27 October, 2009

available on-line: 10 November, 2009

\begin{abstract}
The aim of the study was an evaluation of changes in protein level and activity of SOD isoenzymes, and the participation of AP-1 and NF- $\kappa$ B in subsequent stages of colorectal cancer development. Studies were conducted on 65 colorectal cancers. Controls were unchanged colon regions. Activity of SOD isoenzymes, lipid peroxidation level (TBARS), and protein level of SOD1, SOD2, AP-1 and NF- $\mathrm{B}$ were determined. We found that the protein level and activity of SOD isoenzymes and protein level of AP-1 and NF- $\mathrm{B}$ change in subsequent stages of clinical advancement of colorectal cancer, according to UICC (I-IV), and in grades of tumor cells differentiation $\left(G_{1}-G_{3}\right)$. These results indicate adaptation of colorectal cancer cells to oxidative stress, and show that the observed changes of SOD activity and protein level depend on gradual progression of colorectal cancer, and suggest an impairment of processes regulated by AP-1 and NF- $\kappa$ B which are critical for tumor progression (proliferation, differentiation and apoptosis).
\end{abstract}

Keywords: reactive oxygen species, colorectal adenocarcinoma, superoxide dismutase, transcription factors

\section{INTRODUCTION}

Colorectal cancer (CRC) is the third most common cancer worldwide. The incidence of CRC is higher in countries in the developed world, where it is the second most common cancer. CRC has a leading position in malignant cancer-related morbidity and mortality.

The percentage ratio of CRC mortality in the Polish population, was 10.6 for women and 19.17 for men in 2004 (according to the Polish National Cancer Registry). The risk factors for colorectal cancer are: hereditary genetic predisposition (i.e. familial adenomatous polyposis), age, ulcerative colitis and other colon inflammatory diseases, diets high in meat and fat or low in selenium, Lynch syndrome, smoking, and others (Benson, 2007) ${ }^{1}$.
Colon cancers most commonly occur in the large intestine. The predominant localization of CRC is rectum (50-60\%) and sigmoid colon (15-25\%). Tumors of epithelial origin are definitely the most frequent, among them adenocarcinoma is ubiquitous.

The development of CRC is multistage, beginning with a small dysplasia or polyp, and eventually leading to the appearance of distant metastases to other organs (Ballinger \& Anggianasah, 2007).

Growing evidence indicates the participation of reactive oxygen species (ROS) and their reactive derivatives in the arising and development of colorectal cancer. Inflammantion and environmental factors (nutrition antigenes, bacteria, fungi, parasites), lead to the generation of large amounts of ROS in colon tissue, and in consequence to oxidative stress. Reactive oxygen species damage DNA, proteins and lip-

\footnotetext{
${ }^{\square}$ Corresponding author: Hanna Czeczot, Chair and Department of Biochemistry, Warsaw Medical University, St. Banacha 1, 02-097 Warszawa, Poland; phone: (48) 22572 0693; fax: (48) 22572 0679; e-mail: hanna.czeczot@wp.pl

Abbreviations: AP-1, activating protein 1; CRC, colorectal cancer; $\mathrm{Cu}, \mathrm{Zn}-\mathrm{SOD}$, SOD1, cytosolic superoxide dismutase; EC-SOD, SOD3, extracellular superoxide dismutase; Mn-SOD, SOD2, mitochondrial superoxide dismutase; NF- $\mathrm{kB}$, nuclear factor $\kappa B$; ROS, reactive oxygen species; SOD, superoxide dismutase; PMSF, phenylmethylsulfonyl frluoride; TBARS, thiobarbituric acid reactive substances; UICC, Union Internationale Contre le Cancer.

${ }^{1}$ Colon and rectum (2002) In: American Joint Committee on Cancer.: AJCC Cancer Staging Manual. 6th edn, pp 113-124. Springer, New York, NY.
} 
ids, leading to initiation of tumor changes (Conner \& Grisham, 1996; Olinski et al., 1998; Ohshima et al., 2003; Hussain et al., 2003; Itzkowitz \& Yio, 2004;).

Superoxide dismutase (SOD) is a key antioxidant enzyme, scavenging the superoxide radical $\left(\mathrm{O}_{2}^{-}\right)$, which is a precursor molecule for all other reactive oxygen species and their derivatives. By scavenging $\mathrm{O}_{2}^{-}$, SOD form the first line of defence against oxidative stress and its subsequent effects. In human cells three isoenzymes of SOD exist: cytosolic $(\mathrm{Cu}, \mathrm{Zn}-\mathrm{SOD}$; SOD1), mitochondrial (Mn-SOD; SOD2) and extracellular (EC-SOD, SOD3). Disturbances in the functioning of the SOD isoforms lead to numerous pathological changes in the human organism, including tumor disease (Zelko et al., 2002; Johnson \& Giulivi, 2005).

Expression of SOD genes is regulated by numerous transcription factors, particularly those sensitive to oxidative stress: AP-1 (activating protein 1) and NF- $\kappa B$ (nuclear factor $\kappa B$ ). Synthesis and activation of AP-1 and NF- $\mathrm{KB}$ are among the most important components of the cell response to oxidative stress, and participate in decisions concerning cell survival (proliferation, growth and differentiation) or death (apoptosis) (Karin, 1995; 1999; Wang et al., 2002; Shaulian \& Karin, 2002; Bubici et al. 2006).

Tumor cells are particularly exposed to high oxidative stress conditions, and the role of AP- 1 and $\mathrm{NF}-\mathrm{KB}$ in the regulation of SOD gene expression should have an even greater meaning in tumor than in normal cells (Greten \& Karin, 2004; Kundu \& Surh, 2004; Nicco et al., 2005). The role of SOD and $\mathrm{AP}-1$ and NF- $\mathrm{KB}$ in colorectal cancer progression is still not exactly understood.

Although many authors have studied expression and activities of SOD isoenzymes in tumors, they reported conflicting results. Some of them observed increased expression and activity of SOD isoenzymes in various types of tumors (Janssen et al., 1999; 2000; Kanbagli et al., 2000; Devi et al., 2000; Hileman et al., 2004), while others showed a decreased or unchanged expression and activity of SOD isoenzymes (Casaril et al., 1994, Van Driel et al., 1997; Jung et al., 1997; Preuss et al., 2000; Wang et al., 2005). One explanation of such discrepancies is that they studied tumors in different stages of clinical advancement.

The aim of our work was to determine if the SOD isoenzymes' protein level and their activity depend on the stage of clinical advancement of CRC. We evaluated the protein level and activity of SOD isoenzymes (SOD1, SOD2) and the participation of transcription factors AP- 1 and NF- $\kappa$ B in subsequent stages of clinical advancement (UICC) and the grade of differentiation $(G)$ of human colorectal cancer.

\section{MATERIALS AND METHODS}

Patients and tumor characteristic. Studies were conducted on a group of 65 patients, mean age $62 \pm 9.7$ years (range 44-82), operated on for colorectal cancer, histological type - adenocarcinoma (Table 1). The time since the diagnosis of cancer varied from a minimum of 3 weeks to a maximum of 2 months.

Patients were hospitalized in the Department of General and Gastroenterological Surgery and Nutrition, the Department of General, Transplantation and Liver Surgery, and in the Department of General and Transplantation Surgery at the Warsaw Medical University.

Cancer specimens were taken by surgery, and normal mucosa (control tissue) was taken from corresponding adjacent tissue more than 6-7 $\mathrm{cm}$ away from tumor border (histologically examined).

Cancers were diagnosed by routine surgical and histopathological examination.

Evaluation of colorectal cancer clinical advancement involves such cancer features as: size, penetration of colon tissue and outside, lymph node and vascular invasion, presence of distant metastases. Those features allow exact determination of the clinical advancement stage, according to a classification known as UICC (Union Internationale Contre le Cancer) based on the TNM (Tumor, Node, Metastases) division.

During the development of CRC, cancer cells undergo gradual dedifferentiation. According to WHO, for evaluation of differentiation of cancer cells and tumor maturity, the $G$ (grading) classification is applied. The grade reflects the degree of cellular differentiation and refers to how much the tumor cells resemble or differ from the normal cells of the same tissue type (Ballinger \& Anggiansah, 2007).

Exclusion criteria. Patients were nonsmokers, and not treated by radio- or chemotherapy before surgery.

Table 1. Characteristics of patients studied

\begin{tabular}{ll}
\hline & Colon cancer \\
\hline $\begin{array}{l}\text { Number of patients } \\
\text { Gender (male/female) } \\
(\mathrm{n} / \mathrm{n})\end{array}$ & 65 \\
Mean age (years) & $35 / 30$ \\
Age range (years) & $65.8 \pm 11.4$ \\
Diagnosis & Colorectal adenocarcinoma \\
Staging (n) (UICC) & $\mathrm{I}(9), \mathrm{II}(23), \mathrm{III}(18), \mathrm{IV}(15)$ \\
Grading (n) (G) & $\mathrm{G} 1(11), \mathrm{G} 2(41), \mathrm{G} 3(13)$ \\
Control & Normal colon adjacent \\
& to cancer* $\mathrm{n}=65$ \\
\hline
\end{tabular}

*Since control tissues are adjacent to cancers, number, age and gender proportions are the same as for cancer tissue. 
Sample preparation. Directly after surgery, tissue specimens were washed in cold $0.9 \% \mathrm{NaCl}$ and frozen at $-70^{\circ} \mathrm{C}$. Then the tissues were cut to smaller pieces and homogenized in 9 vol. of cooled $100 \mathrm{mM}$ Tris/ $\mathrm{HCl}$ buffer (pH 7.5) containing $100 \mathrm{mM}$ $\mathrm{KCl}, 1 \%(\mathrm{v} / \mathrm{v})$ Triton $\mathrm{X}-100$, and $0.5 \mathrm{mM}$ PMSF, in a Heidolph Diax homogenizer. After $30 \mathrm{~min}$ of extraction on a magnetic stirrer, homogenates were frozen at $-70^{\circ} \mathrm{C}$. After $24 \mathrm{~h}$ they were thawed and centrifuged at $12000 \times g$ for $30 \mathrm{~min}$ at $4^{\circ} \mathrm{C}$. The obtained tissue extracts (supernatants) were used for determination of $\mathrm{Cu}, \mathrm{Zn}-\mathrm{SOD}$ and Mn-SOD activity and protein level of SOD isoenzymes, AP-1 and NF-кB.

Biochemical analyses. a) Determination of $l i-$ pid peroxidation level. One of the consequences of oxidative stress in cells is lipid peroxidation. This is a chain reaction whose end products (malondialdehyde, 4-hydoxynonenal, and others) are used as markers of lipid peroxidation level, and indirectly as markers of oxidative stress intensity. The lipid peroxidation level was expressed as the concentration of substances reacting with thiobarbituric acid (TBARS). The concentration of TBARS was measured according to the method described by Ohkawa et al. (1979).

b) Determination of activity of SOD isoenzymes. The activity of SOD1 was measured by a standard RanSOD kit purchased from Randox. This method applies xanthine and xanthine oxidase to generate superoxide anion which reacts with 2-(4-iodophenyl)-3-(4-nitrophenol)-5-phenyltetrazolium chloride (INT) to form a red formazan dye. The superoxide dismutase activity is then measured by the degree of inhibition of this reaction. It is specific for SOD1 activity only.

The activity of SOD2 was determined according to the method described by Beauchamp and Fridovich (1971), modified by Oberley and Spitz (1984). The superoxide anion generated by xanthine oxidase reacts with 2,2'-di-p-nitrophenyl-5, $5^{\prime}$-diphenyl-3,3'-[3,3'-dimethoxy-4,4' -diphenylene]-ditetrazolium chloride (nitro blue tetrazolium - NBT) forming a blue dye. Manganese superoxide dismutase activity is then measured by the degree of inhibition of this reaction. Application of $\mathrm{NaCN}$ which is a SOD1 inhibitor renders this reaction specific for SOD2 activity.

c) Determination of protein levels of SOD isoenzymes and transcription factors. Protein levels of SOD1, SOD2, AP-1 and NF- $\mathrm{KB}$ were determined using a standard Western blotting technique. Immunoelectrophoretic determination of SOD isoforms and the AP-1 and NF- $\mathrm{kB}$ transcription factors was performed by separation of samples prepared according to the method described by Laemmli (1970) on a $14 \%$ polyacrylamide gel containing $0.1 \%$ sodium dodecyl sulfate. This was followed by semi-dry electro- transfer on to a PVDF membrane. To block nonspecific binding, the PVDF membrane was preincubated with TTBS (Tris-buffered saline, $\mathrm{pH}$ 7.6, containing $0.05 \%$ Tween-20 and $10 \%$ nonfat milk) for $1 \mathrm{~h}$. The membrane was then incubated with anti-SOD1, antiSOD2, anti-AP-1 or anti-NF-kB antibodies for $1.5 \mathrm{~h}$ at room temperature. After incubation, the membrane was washed with TTBS and then incubated with secondary antibodies conjugated with horseradish peroxidase (Ausubel et al., 2000). The bound antibodies were detected by chemiluminescence with the ECL kit (Amersham Life Sciences).

The amount of the proteins studied was measured densitometrically using a relative level (optical density) UVI-KS 4000 I camera and programs ScionImage and ZERO-DSCAN.

Polyclonal anti-SOD1 and anti-SOD2 antibodies were purchased from Calbiochem, and diluted 1:2000 and 1:500, respectively. Monoclonal anti-p65 and anti c-Jun antibodies were purchased from Sigma and diluted $1: 1000$ and $1: 500$, respectively. The presence of p65, c-Jun and $\mathrm{Cu}, \mathrm{Zn}-\mathrm{SOD}$ in the biological material examined was confirmed with the use of protein standards: recombinant human p65 and cJun and purified SOD1 enzyme from human erytrocytes. The presence of SOD2 protein was confirmed on the basis of its known subunit molecular weight with the use of molecular weight marker (Rainbow Colour High Range).

To confirm equal load of proteins on the gel, after removal of antibodies by stripping in reducing buffer, the PVDF membrane was incubated again with antibodies against actin (Santa Cruz).

Statistical analysis. The data of TBARS level, and the activity and protein level of SOD isoenzymes, and the levels of transcription factors AP-1 and NF$\kappa \mathrm{B}$, are presented as mean values and standard deviations $(x \pm$ S.D.). The level of TBARS is expressed in $\mathrm{nmol} / \mathrm{mg}$ of total protein, the activity of SOD isoforms in U/mg of total protein, and the amount of studied proteins in optical density values (OD).

Statistical analysis of data was conducted using Statistica 6.0 programme. Student's $t$-test and Wilcoxon test were applied for comparison of variables.

Studies were approved by the Bioethics Committee the Warsaw Medical University (decision $\mathrm{KB} / 164 / 2001$ ), and informed consent was obtained from all patients.

\section{RESULTS}

\section{Level of lipid peroxidation}

The highest level of lipid peroxidation was observed in stage I of CRC clinical advancement (UICC) 
a) CuZnsod

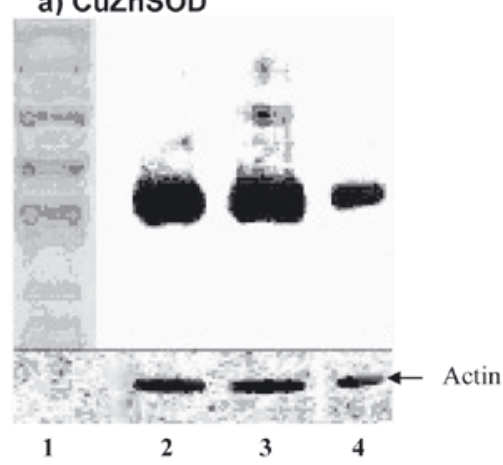

c) AP-1

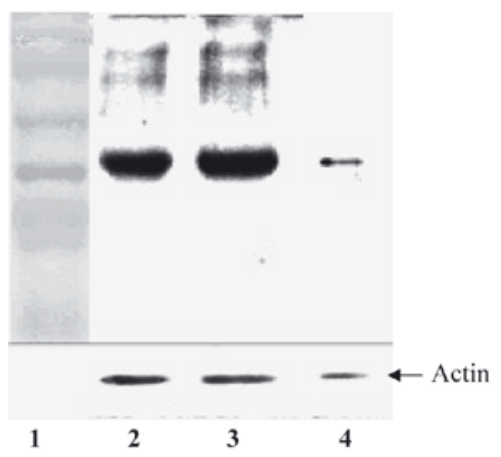

b) MnSOD

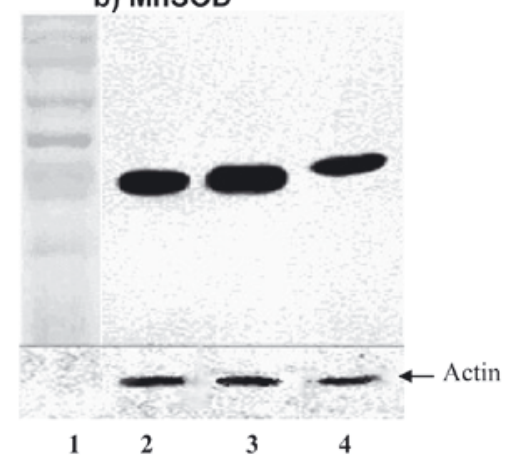

d) NF-kB

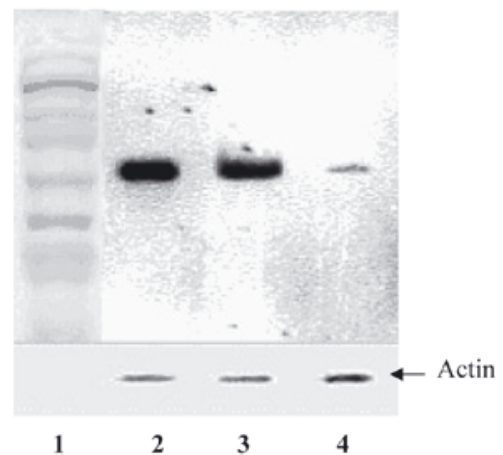

Figure 1. Western blots of SOD isoforms and transcription factors AP-1 and NF- $\mathrm{kB}$ in colorectal adenocarcinomas

Lanes: 1, molecular weight marker; 2, control tissue (normal colon); 3, colorectal adenocarcinoma; 4, standards for: $\mathrm{Cu}, \mathrm{Zn}-\mathrm{SOD}, \mathrm{Mn}-$ SOD, AP-1, NF-кB. and $G_{1}$ grade of tumor cell differentiation $\left(G_{1}-G_{3}\right)$. In stages II, III and IV the level of TBARS was lower than in stage I, and even lower than in control.

The lowest level of TBARS comparing with control and $G_{1}$ grade was observed in $G_{2}$ grade. In the $G_{3}$ differentiation grade an increased level of TBARS was found in comparison with the $G_{2}$ grade (Fig. 2a, b).

\section{Activity of SOD1 and SOD2}

In all stages of colorectal cancer development (UICC I-IV, $\mathrm{G}_{1}-\mathrm{G}_{3}$ ) similar levels of SOD1 activity were found. In comparison with the control, significant changes of SOD1 activity were observed in stages I and II of UICC. Comparing to the control, the activity of SOD1 in colorectal cancer $G_{1}$ grade was increased, in $G_{2}$ was at the control level, and in $\mathrm{G}_{3}$ decreased (Fig. 3a, b).

The highest activity of SOD2 was observed in stages II and IV of UICC, comparing with stages I, III, and control. There were no significant changes of SOD2 activity in the $\mathrm{G}_{1}-\mathrm{G}_{3}$ grades of CRC differentiation. In stages I and III the activity of SOD1 was distinctly higher, whereas in stages II and IV the activity of SOD2 was higher (Fig. 3a, b).

\section{Protein levels of SOD isoenzymes and transcription factors AP-1 and NF- $\kappa$ B}

In stages I and IV of UICC a very high level of SOD1 protein was observed, and relatively lower protein levels of SOD2, AP-1 and NF-кB. In compar- ison with stage I of UICC, in stage II we observed a distinct (54\%) decrease of SOD1 protein level and simultaneously increased protein levels of SOD2, AP-1 and NF-кB. In stage III, the protein levels of SOD1 and SOD2 were similar, while those of AP-1 and $\mathrm{NF}-\kappa \mathrm{B}$ were substantially less abundant. A low level of $N F-\kappa B$ was also seen in stage IV of UICC. The highest level of SOD1 protein was observed in stages I and IV, and SOD2 in II and III. The highest level of both transcription factors (AP-1 and NF-kB) was in stage II of UICC, and the lowest in stage III.

The protein levels of SOD1 and NF-kB were lower in subsequent grades of differentiation $\left(G_{2}\right.$ and $G_{3}$ ) of CRC in comparison with the $G_{1}$ stage. SOD2 protein level was the highest in $G_{1}$ grade, and the lowest in $G_{2}$, whereas the AP-1 protein level was the lowest in $G_{2}$ grade comparing to $G_{1}$ and $G_{3}$ (Fig. 4a, b).

\section{DISCUSSION}

We observed significant differences in the activity and protein level of both SOD isoenzymes, and the protein level of transcription factors AP-1 and NF- $\mathrm{KB}$ among the subsequent stages of CRC development. Those differences were associated with different levels of TBARS and seem to be due to the redox state of tumor cells, which differ depending on the advancement stage of colorectal cancer.

Since the lipid peroxidation level corresponds to the level of oxidative stress, our results 

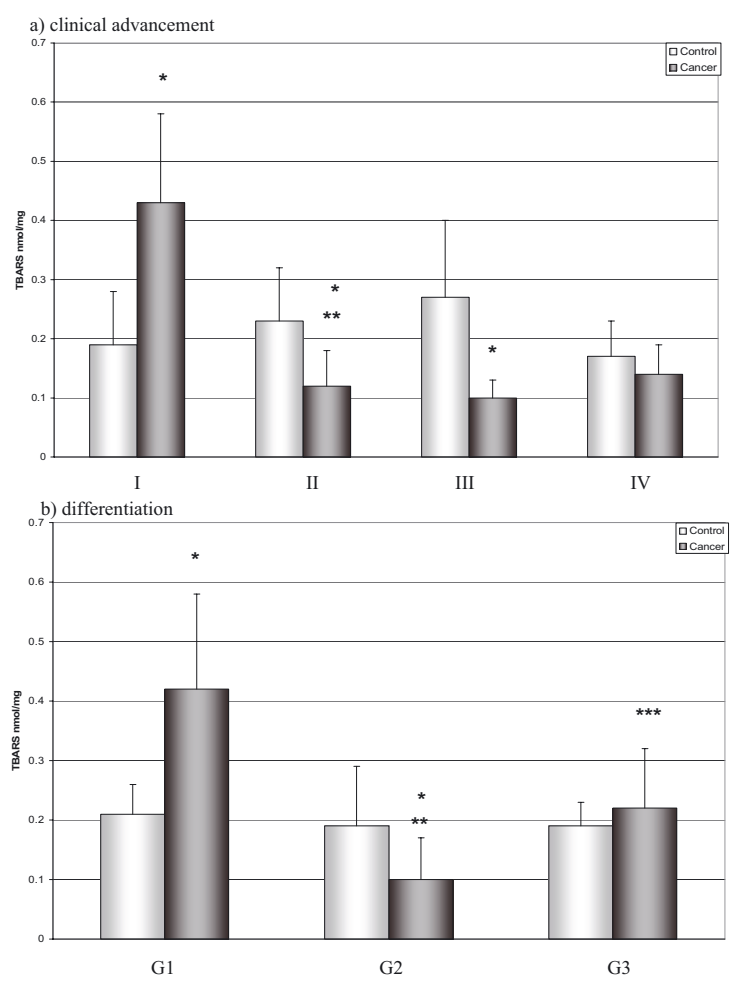

Figure 2. TBARS level in subsequent stages of CRC clinical advancement and differentiation.

a) *significant versus control tissue $(P<0.05)$; ${ }^{* *}$ significant versus stage I of cancer $(P<0.05)$; I-IV, UICC stages of colorectal cancer clinical advancement; b) *significant versus control tissue $(P<0.05) ;{ }^{* *}$ significant versus $G_{1}$ stage $(P<0.05)$; ${ }^{* * *}$ significant versus $\mathrm{G}_{2}$ stage $(P<0.05) ; \mathrm{G}_{1}-\mathrm{G}_{3^{\prime}}$ grades of colorectal cancer differentiation.

indicate oxidative stress conditions at the initial stages of CRC clinical advancement (UICC I) and differentiation $\left(G_{1}\right)$. In the subsequent stages of CRC development, regarding both clinical advancement (II-IV) and differentiation $\left(\mathrm{G}_{2}-\mathrm{G}_{3}\right)$, the oxidative stress seems to be low. Therefore, the oxidative stress at the initial stages of CRC development might be a result of accompanying inflammation. The oxidative stress might be regarded as selective pressure, and only those tumor cells that adapt to it would be able to undergo further cancer development (Huang et al., 2000; Pelicano et al., 2004). This might explain the low level of lipid peroxidation in subsequent stages of CRC development.

The study results show that during whole cancer development tumor cells have a stable level of antioxidative defense provided by SOD1 present in the cytosol. However, an increased protein level of SOD1 might be a response to the high level of ROS which has been previously confirmed by Yoo et al. (1999a). This might suggest that ROS present in tumor cells stimulate the expression of SOD1 protein, but simultaneously partly reduce

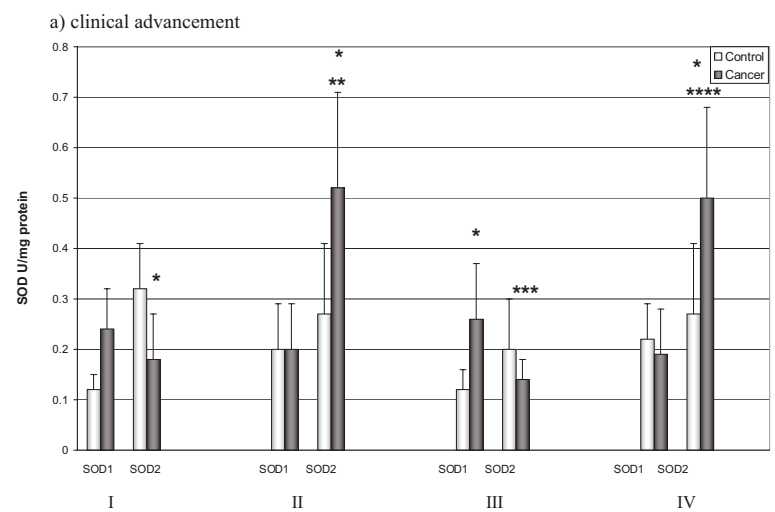

b) differentiation

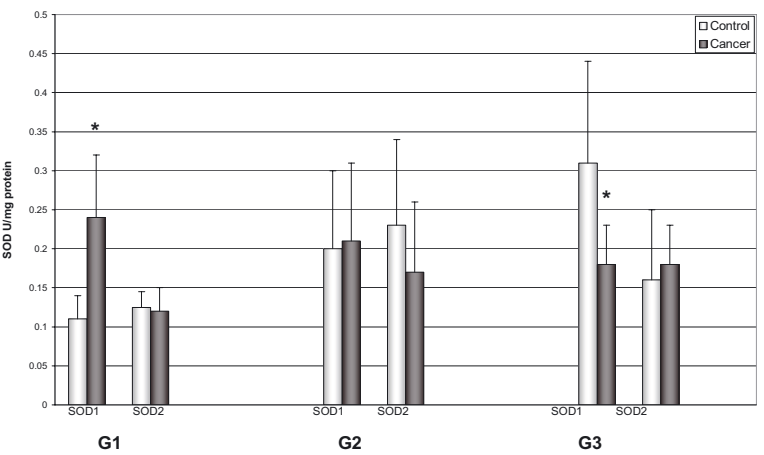

Figure 3. Activity of SOD isoenzymes in subsequent stages of CRC clinical advancement and differentiation a) *significant versus control tissue $(P<0.05)$; ${ }^{* *}$ significant versus stage I of cancer $(P<0.05)$; ${ }^{* * *}$ significant versus stage II of cancer $(P<0.05)$; ${ }^{* * *}$ significant versus stage III of cancer $(P<0.05)$; I-IV, UICC stages of colorectal cancer clinical advancement; $\mathbf{b})$ *significant versus control tissue $(P<0.05)$; $G_{1}-G_{3}$, grades of colorectal cancer differentiation.

SOD1 activity. Despite the low level of lipid peroxidation, it seems that ROS still might affect the antioxidant defense of tumor cell, which has been shown in the earlier studies (Suh et al., 1999; Nicco et al., 2005). This suggests that SOD1, despite its low activity could be able to defend cellular structures against oxidative stress.

The activity of the mitochondrial isoenzyme - SOD2 - varies significantly in the subsequent stages of UICC, but is almost unchanged in all stages of CRC differentiation.

This result indicates that the changes of SOD2 activity during CRC development have a distinctly periodic character, that is: it decreases in stage I, followed by an increase in stage II, a decrease in stage III and again an increase in stage IV. The factor that could cause such changes in SOD2 activity might be its product - hydrogen peroxide $\left(\mathrm{H}_{2} \mathrm{O}_{2}\right)$, which is able to reversibly inhibit SOD activity via a feedback mechanism. In previously published papers (Mao et al., 1993; Koningsberger et al., 1994; Bergendi et al., 1999; Antunes \& Cadenas, 2001) this feedback inhibition was found to be one of the mechanisms controlling $\mathrm{H}_{2} \mathrm{O}_{2}$ level. The discrepancy between the 

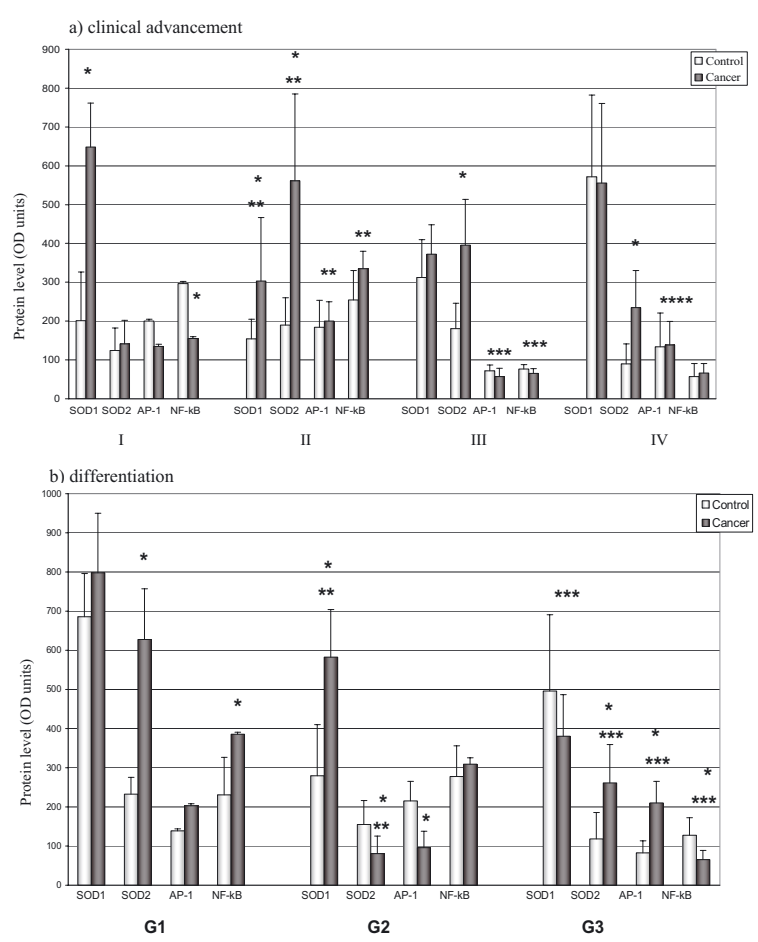

Figure 4. Protein level of SOD isoenzymes, AP-1 and NF- $\kappa B$ in subsequent stages of CRC clinical advancement and differentiation.

a) *significant versus control tissue $(P<0.05)$; ${ }^{* *}$ significant versus stage I of cancer $(P<0.05) ;{ }^{* * *}$ significant versus stage II of cancer $(P<0.05) ;{ }^{* * * *}$ significant versus stage III of cancer $(P<0.05)$; I-IV, UICC stages of colorectal cancer clinical advancement; b) *significant versus control tissue $(P<0.05)$; **significant versus $\mathrm{G}_{1}$ stage $(P<0.05)$; ${ }^{* * *}$ significant versus $\mathrm{G}_{2}$ stage $(P<0.05) ; \mathrm{G}_{1}-\mathrm{G}_{3}$, grades of colorectal cancer differentiation.

protein level and activity of SOD2 might also confirm these observations. Hydrogen peroxide might affect also SOD2 expression via ROS-sensitive transcription factors.

The SOD2 protein level in subsequent grades of CRC differentiation also varies in a periodic manner: $G_{1}-$ increase, $G_{2}$ - decrease, $G_{3}$ - increase. However, its activity generally remains at the same level. It seems that inhibition by hydrogen peroxide also occurs here, but whereas progression of CRC in the clinical advancement causes an inflammatory state (and oxidative stress) due to the growth inside the intestine wall, the differentiation is the change of the histology and morphology of the cell and does not affects the redox state of the cell by itself. Therefore the changes of SOD protein level during differentiation could only be a secondary phenomenon dependent on the action of transcription factors that simultaneously control SOD's expression and participate in the regulation of cell differentiation.

The transcription factors AP- 1 and NF- $\kappa B$ participate in the control of cell differentiation, and also in the regulation of expression of SOD1 and
SOD2 (Borrello \& Demple, 1997; Wang et al., 2002; Floryk \& Huberman, 2005; Mehic et al., 2005). The expression profile of AP-1 and NF- $\mathrm{kB}$ varies similarly in all stages of CRC clinical advancement. Probably those changes are a response to the changing redox conditions during cancer development. Since they are ROS-sensitive, the changes of their protein level might be a manifestation of the tumor cell adaptation to the increasing levels of ROS. However, the protein levels of AP-1 and NF$\kappa \mathrm{B}$, seems not to be directly related to the SOD1 and SOD2 protein levels. This suggests participation of other ROS-sensitive transcription factors, and regulation of SOD expression by a more complicated network of intracellular signaling (Seo et al., 1996; Hyoung-Pyo et al., 1999; Gopalakrishna \& Jaken, 2000; Guo et al., 2003).

In the subsequent stages of CRC differentiation the protein level of AP- 1 varies in a periodic manner, and the protein level of NF- $\mathrm{KB}$ decreases. The two transcription factors regulate differentiation in opposite manner. Their expression profile leads eventually to full dedifferentiation in the $\mathrm{G}_{3}$ grade. The high level of oxidative stress in grade $\mathrm{G}_{1}$ might impair the activation and expression of AP-1 and NF- $\kappa$ B, in turn leading to initiation of changes in cell differentiation (Ryborg et al., 2004; Eliseev et al., 2006).

The relations between the SOD protein levels and those of $\mathrm{AP}-1$ and $\mathrm{NF}-\mathrm{\kappa B}$ in subsequent grades of CRC differentiation are unclear. Some protein levels of SOD and AP-1 and NF- $\mathrm{KB}$ change in similar manner, but this is not a rule, and influence of other factors cannot be ruled out.

The protein levels and activities of SOD isoenzymes (SOD1, SOD2) clearly change in subsequent stages of clinical advancement (UICC) and grades of differentiation $(\mathrm{G})$ of human colorectal cancer. These changes seems to be dependent first of all on the clinical advancement of CRC (UICC). It is not clear if changes in SOD level are directly related to the differentiation process.

Our results also suggest that changes of protein level and activity of SOD isoenzymes might be an adaptive response to the oxidative stress, which appears during progression of CRC.

The participation of the AP-1 and NF- $\mathrm{BB}$ transcription factors in CRC progression seems to be mainly related to the stimulation of cell antioxidative response to oxidative stress. However, they also regulate such processes as proliferation, differentiation and apoptosis, and changes of their protein level, excessive activation, or impaired action might be a direct cause of carcinogenic transformation and further development of tumor disease.

It seems that the redox status of cancer cells has a great influence on tumor progression. SOD 
isoenzymes are one of the main controllers of the redox state, therefore therapies affecting SOD activity or expression (i.e., SOD inhibitors, gene knockout) in cancers at different stages of tumor advancement could aid in elimination of cancer cells.

\section{Acknowledgement}

This work was supported by grants from the Warsaw Medical University: 1WK/W1/08 and 1WK/ W1/09.

\section{REFERENCES}

Antunes F, Cadenas E (2001) Cellular titration of apoptosis with steady state concentrations of $\mathrm{H}_{2} \mathrm{O}_{2}$ : submicromolar levels of $\mathrm{H}_{2} \mathrm{O}_{2}$ induce apoptosis through Fenton chemistry independent of the cellular thiol state. Free Radic Biol Med 30: 1008-1018.

Ausubel FM, Brent R, Kingstone RE, Moore DD, Seidman JG, Smith JA, Struhl K (2000) Current Protocols in Molecular Biology; vol 2. Wiley J, Massachusets General Hospital, Harvard Medical School.

Ballinger AB, Anggiansah C (2007) Colorectal cancer. BMJ 335: 715-718.

Beauchamp C, Fridovich I (1971) Superoxide dismutase: improved assays and an assay applicable to acrylamide gels. Anal Biochem 44: 276-287.

Benson AB 3rd (2007) Epidemiology, disease progression, and economic burden of colorectal cancer. J Manag Care Pharm 13: S5-S18.

Bergendi L, Benes L, Durackova Z, Ferencik M (1999) Chemistry, physiology and pathology of free radicals. Life Sci 65: 1865-1874.

Borrello S, Demple B (1997) NF kappa B-independent transcriptional induction of the human manganous superoxide dismutase gene. Arch Biochem Biophys 348: 289-294.

Bubici C, Papa S, Pham CG, Zazzeroni F, Franzoso G (2006) The NF-kappaB-mediated control of ROS and JNK signaling. Histol Histopathol 21: 69-80.

Casaril M, Corso F, Bassi A, Capra F, Gabrielli GB, Stanzial AM, Nicoli N, Corrocher R (1994) Decreased activity of scavenger enzymes in human hepatocellular carcinoma, but not in liver metastases. Int J Clin Lab Res 24: 94-97.

Conner EM, Grisham MB (1996) Inflammation, free radicals and antioxidants. Nutrition 12: 274-277.

Devi GS, Prasad MH, Saraswathi I, Raghu D, Rao DN, Reddy PP (2000) Free radicals antioxidant enzymes and lipid peroxidation in different types of leukemias. Clin Chim Acta 293: 53-62.

Eliseev RA, Schwarz EM, Zuscik MJ, O'Keefe RJ, Drissi H, Rosier RN (2006) Smad7 mediates inhibition of Saos2 osteosarcoma cell differentiation by NFkB. Exp Cell Res 312: $40-50$

Floryk D, Huberman E (2005) Differentiation of androgenindependent prostate cancer PC-3 cells is associated with increased nuclear factor- $\kappa \mathrm{B}$ activity. Cancer Res 65: 11588-11596.

Gopalakrishna R, Jaken S (2000) Protein kinase C signaling and oxidative stress. Free Radic Biol Med 28: 1349-1361.
Greten FR, Karin M (2004) The IKK/NF- $\mathrm{B}$ activation pathway - a target for prevention and treatment of cancer. Cancer Lett 206: 193-199.

Griffioen G, Lamers CB, van Krieken JH, van de Velde CJ, Verspaget HW (2000) Superoxide dismutases in gastric and esophageal cancer and the prognostic impact in gastric cancer. Clin Cancer Res 6: 3183-3192.

Guo G, Yan-Sanders Y, Lyn-Cook BD, Wang T, Tamae D, Ogi J, Khaletskiy A, Li Z, Weydert C, Longmate JA, Huang TT, Spitz DR, Oberley LW, Li JJ (2003) Manganese superoxide dismutase-mediated gene expression in radiation-induced adaptive responses. Mol Cell Biol 23: 362-378.

Hileman EO, Liu J, Albitar M, Keating MJ, Huang P (2004) Intrinsic oxidative stress in cancer cells: a biochemical basis for therapeutic selectivity. Cancer Chemother Pharmacol 53: 209-219.

Huang P, Feng L, Oldham EA, Keating MJ, Plunkett W (2000) Superoxide dismutase as a target for the selective killing of cancer cells. Nature 407: 390-395.

Hussain SP, Hofseth LJ, Harris CC (2003) Radical causes of cancer. Nat Rev Cancer 3: 276-285.

Hyoung-Pyo K, Jung-Hye RP, Boon C, Moon BY (1999) Transcriptional activation of the human manganese superoxide dismutase gene mediated by tetradecanoylphorbol acetate. J Biol Chem 271: 37455-37460.

Janssen AM, Bosman CB, Kruidenier L, Griffioen G, Lamers $\mathrm{CB}$, van Krieken $\mathrm{JH}$, van de Velde CJ, Verspaget HW (1999) Superoxide dismutases in the human colorectal cancer sequence. J Cancer Res Clin Oncol 125: 327335.

Janssen AM, Bosman CB, van Duijn W, Oostendorp-van de Ruit MM, Kubben FJ, Kanbagli O, Ozdemirler G, Bulut T, Yamaner S, Aykac-Toker G, Uysal M (2000) Mitochondrial lipid peroxides and antioxidant enzymes in colorectal adenocarcinoma tissues. Jpn J Cancer Res 91: 1258-1263.

Johnson F, Giulivi C (2005) Superoxide dismutases and their impact upon human health. Mol Asp Med 26: 340352.

Jung K, Seidel B, Rudolph B, Lein M, Cronauer MV, Henke W, Hampel G, Schnorr D, Loening SA (1997) Antioxidant enzymes in malignant prostate cell lines and in primary cultured prostatic cells. Free Radic Biol Med 23: 127-133.

Karin M (1995) The regulation of AP-1 activity by mitogenactivated protein kinases. J Biol Chem 270: 16483-16486.

Karin M (1999) How NF-kB is activated: the role of IkB kinase (IKK) complex. Oncogene 18: 6867-6874.

Koningsberger JC, van Asbeck BS, van Fassen E, WIegman LJ, van Hattun J, van Berge Henegouwen GP, Marx J (1994) Copper, zinc - superoxide dismutase and hydrogen peroxide: a hydroxyl radical generating system. Clin Chim Acta 230: 51-61.

Kundu JK, Surh YJ (2004) Molecular basis of chemoprevention by resveratrol: NF-kB and AP-1 as potential targets. Mutat Res 555: 65-80.

Laemmli UK (1970) Cleavage of structural proteins during the assembly of the head of bacteriophage T4. Nature 227: 680-685.

Mao GD, Thomas PD, Lopaschuk GD, Poznansky MJ (1993) Superoxide dismutase (SOD) - catalase conjugates. Role of hydrogen peroxide and Fenton reaction in SOD toxicity. J Biol Chem 268: 416-420.

Mehic D, Bakiri L, Ghannadan M, Wagner EF, Tschachler E (2005) Fos and jun proteins are specifically expressed during differentiation of human keratinocytes. J Invest Dermatol 124: 212-220. 
Nicco C, Laurent A, Chereau C, Weill B, Batteux F (2005) Differential modulation of normal and tumor cell proliferation by reactive oxygen species. Biomed Pharmacother 59: 169-174.

Oberley LW, Spitz DR (1984) Assay of superoxide dismutase activity in tumor tissue. Methods Enzymol 105: 457-464.

Ohkawa H, Ohishi N, Yagi K (1979) Assay for lipid peroxides in animal tissues by thiobarbituric acid reaction. Anal Biochem 95: 351-358.

Ohshima H, Tatemichi M, Sawa T (2003) Chemical basis of inflammation-induced carcinogenesis. Arch Biochem Biophys 417: 3-11.

Olinski R, Jaruga P, Zastawny TH (1998) Oxidative DNA base modifications as factors in carcinogenesis. Acta Biochim Polon 45: 561-572.

Pelicano H, Carney D, Huang P (2004) ROS stress in cancer cells and therapeutic implications. Drug Resist Updat 7: 97-110.

Ryborg AK, Johansen C, Iversen L, Kragballe K (2004) Lysophosphatidylcholine induces keratinocyte differentiation and upregulation of AP-1- and NF- $\kappa$ B DNA-binding activity. Acta Derm Venereol 84: 433-438.

Seo SJ, Kim HT, Cho G, Rho HM, Jung G (1996) Sp1 and $\mathrm{C} / \mathrm{EBP}$-related factor regulate the transcription of human $\mathrm{Cu} / \mathrm{ZnSOD}$ gene. Gene 178: 177-185.

Shaulian E, Karin M (2002) AP-1 as a regulator of cell life and death. Nature Cell Biol 4: E131-E136.
Suh YA, Arnold RS, Lassegue B, Shi J, Xu X, Sorescu D, Chung AB, Griendling KK, Lambeth JD (1999) Cell transformation by the superoxide-generating oxidase Mox1. Nature 401: 79-82.

Van Driel BE, Lyon H, Hoogenraad DC, Anten S, Hansen U, Van Noorden CJ (1997) Expression of CuZn- and Mn-superoxide dismutase in human colorectal neoplasms. Free Radic Biol Med 23: 435-444.

Wang T, Zhang X, Li JJ (2002) The role of NF-kappaB in the regulation of cell stress responses. Int Immunopharmacol 2: 1509-1520.

Wang SH, Wang YZ, Zhang KY, Shen JH, Zhou HQ, Qiu $X Y$ (2005) Effect of superoxide dismutase and malondialdehyde metabolic changes on carcinogenesis of gastric carcinoma. World J Gastroenterol 11: 4305-4310.

Yoo HY, Chang MS, Rho HM (1999a) The activation of rat coper/zinc superoxide dismutase gene by hydrogen peroxide-responsive element and by paraquat and heat shock through the same heat shock element. J Biol Chem 274: 23887-23892.

Zelko IN, Mariani TJ, Folz RJ (2002) Superoxide dismutase multigene family: A comparison of the $\mathrm{Cu}, \mathrm{ZnSOD}$ (sod1), Mn-SOD (sod2), and EC-SOD (sod3) gene structures, evolution, and expression. Free Radic Biol Med 33: 337-349. 